\title{
Effect of Sea Water Trophic Level on Migration and Deposition
}

\section{of Man-Made Plutonium Radionuclides}

\author{
Nataliya N. Tereshchenko* \\ A.O. Kovalevsky Institute of Marine Biological Research RAS \\ 2 Nakhimov, Sevastopol, 299011, Russia
}

\begin{abstract}
Received 09.01.2017, received in revised form 11.02.2017, accepted 03.03.2017
The comparative analysis of an impact of the trophic level on the redistribution of plutonium radionuclides in marine ecosystems at different spatial scales was carried out for semi-closed coastal areas, the western part of the Black Sea, open areas of the Black and Mediterranean seas. The quantitative characteristics of radioecological processes of the sedimentation of ${ }^{239+240} \mathrm{Pu}$ radionuclides in bottom sediments in the coastal and open areas of the Black Sea, as well as effective half-life of ${ }^{239+240} \mathrm{Pu}$ in the Black Sea surface waters were determined. It was shown that an increase in water trophic level, causing an increase of the suspended matter concentration and sedimentation rate, played a significant role in the redistribution of ${ }^{239+240} \mathrm{Pu}$. There was a strengthening of plutonium pedotrophic properties and increase the rate of self-purification of the Black Sea surface water regarding the plutonium radionuclides by their redistribution into the bottom sediments. Trophic level of sea waters affected the values of the radioecological parameters of the ${ }^{239+240} \mathrm{Pu}$ migration at studied areas, the radioecological status of the sea in the basin regarding the radionuclides of plutonium, and biogeochemical type of $\mathrm{Pu}$ behavior in the seas.
\end{abstract}

Keywords: ${ }^{239,240} \mathrm{Pu}$, migration, sedimentation, trophic level, the Black Sea, Mediterranean Sea.

Citation: Tereshchenko N.N. Effect of sea water trophic level on migration and deposition of man-made plutonium radionuclides. J. Sib. Fed. Univ. Biol., 2017, 10(1), 20-34. DOI: 10.17516/1997-1389-0005.

(C) Siberian Federal University. All rights reserved

* Corresponding author E-mail address: ntereshchenko@yandex.ru 


\section{Влияние трофности морских вод на миграцию \\ и депонирование техногенных \\ радионуклидов плутония}

Н.Н. Терещенко

Институт морских биологических исследований имени А.О. Ковалевского РАН

Россия, 299011, Севастополь, пр. Нахимова, 2

Проведен сравнительный анализ влияния уровня трофности морских вод на процессы перераспределения радионуклидов плутония в морских экосистемах разных масштабов: в полузакрытой прибрежной акватории и в западной части Черного моря, в открытых районах Черного и Средиземного морей. Были определены количественные характеристики радиоэкологических процессов седиментационного депонирования радионуклидов ${ }^{239+240} \mathrm{Pu} в$ донные осадки в прибрежных и открытых районах Черного моря, период полууменьшения ${ }^{239+240} \mathrm{Pu}$ в поверхностной черноморской воде. Показано, что увеличение трофности вод, вызывающее увеличение количества взвеси и скорости осадконакопления, играло существенную роль в перераспределении ${ }^{239+240} \mathrm{Pu}$. Происходит усиление педотропных свойств плутония и увеличение скорости самоочищения поверхностных черноморских вод от радионуклидов плутония благодаря их переходу в донные осадки. Уровень трофности морских вод влиял на значения радиоэкологических параметров миграции ${ }^{239+240} \mathrm{Pu}$ в изученных акваториях, на радиоэкологический статус моря в бассейне в отношении радионуклидов плутония и на биогеохимический тип поведения Ри в водоемах.

Ключевые слова: ${ }^{239+240} \mathrm{Pu}$, миграиия, седиментационное депонирование, уровень трофности, Черное море, Средиземное море.

\section{Введение}

В водных экосистемах от уровня содержания в воде радиоактивных и химических веществ зависит развитие организмов в различных биотопах водоема. Антропогенное загрязнение поступает в водную среду, а дальше мигрирует между абиотическими и биотическими компонентами. В морских экосистемах, как и в любых других, функционирует целый ряд механизмов, которые направлены на обеспечение поддержания уровней характеристик водной среды в диапазоне, приемлемом для развития биоценозов. Мно- гочисленные исследования в области радиохемоэкологии водных и наземных экосистем свидетельствуют о влиянии процессов жизнедеятельности биоты на уровни накопления, формы и судьбу поступающих в нее радиоактивных и химических загрязнений (Морская радиохемоэкология..., 1984; Santschi, Honeyman, 1989; Трапезников, Трапезникова, 2006; Радиоэкологический отклик..., 2008). В частности, это показано для продукционных процессов в черноморских экосистемах (Поликарпов, Егоров, 1986; Терещенко, 1986; Молисмология..., 1992). Одной из основных задач 
радиохемоэкологии является изучение биогеохимических процессов и факторов, влияющих на миграцию и элиминацию из водной среды загрязняющих веществ.

В современный период - эпоху развития ядерных технологий - усиливается влияние на природные экосистемы техногенных радиоактивных веществ, к которым относятся радионуклиды плутония (Pu) (Морская радиохемоэкология..., 1984; Worldwide..., 2005; Радиоэкологический отклик..., 2008; Tereshchenko et al., 2014). Наиболее важное промышленное и радиоэкологическое значение среди них имеют альфа-радионуклиды ${ }^{239,240} \mathrm{Pu}$ (Плутоний..., 2003). Продолжение использования ядерных технологий требует разработки научных основ радиационной защиты природных экосистем, оценки и прогноза радиоэкологической ситуации как в морях в целом, так и в отдельных их акваториях, что невозможно без знания закономерностей миграции и перераспределения радионуклидов в водоеме и ведущих факторов, оказывающих влияние на эти процессы.

Поступление радионуклидов плутония в Черное море в результате ядерных инцидентов предоставило уникальную возможность изучения радиоэкологических и других природных процессов в черноморских экосистемах. Использование радиоактивного загрязнения в качестве инструмента исследования, отводя радионуклидам ${ }^{239,240} \mathrm{Pu}$ роль радиоактивных трассеров природных процессов в водоеме (Радиоэкологический отклик..., 2008; Isotopes..., 2013), дает возможность не только выявлять тенденции процессов, но также исследовать их механизмы и определять, в частности, количественные характеристики перераспределения и миграции радионуклидов плутония в экосистеме. Плутоний относится к элементам, которые активно взаимодействуют с частицами. Он хорошо сорбируется на взвесях и с седиментационным потоком взвеси депонируется в донные отложения, поэтому относится к элементам с педотрофным типом биогеохимического поведения, так называемым элементам-дайверам (Buesseler, Livingston, 1996; Радиоэкологический отклик..., 2008; Терещенко, 2011; Терещенко и др., 2012). Увеличение трофности вод ведет к увеличению количества взвеси в фотическом слое вод. Это должно способствовать увеличению седиментационной миграции радионуклидов плутония в осадки и усилению самоочищающей способности этих вод от радионуклидов плутония. Кроме того, плутоний активно накапливается морскими организмами, в том числе планктоном (Santschi, Honeyman, 1989; Радиоэкологический отклик..., 2008; Tereshchenko et al., 2014). Повышение уровня трофности вод, вызывая увеличение первичной продукции и биомассы, особенно планктона, должно способствовать усилению биогенного потока миграции плутония. Радионуклиды плутония относятся к долгоживущим радионуклидам, их уменьшение за счет радиоактивного распада на масштабе десятков и сотен лет не составляет значимых величин, и их количество в экосистеме практически не уменьшается. Поэтому важно знать закономерности перераспределения ${ }^{239+240} \mathrm{Pu}$, в частности из воды в другие компоненты морских экосистем, особенно скорость самоочищения поверхностных морских вод.

Целью нашей работы было изучение процессов перераспределения радионуклидов плутония в морских экосистемах в районах с разным уровнем трофности. При этом определяли количественные характеристики радиоэкологических процессов седиментационного депонирования радионуклидов ${ }^{239,240} \mathrm{Pu}$ в донные осадки в прибрежных и открытых районах Черного моря, периоды полууменьшения ${ }^{239+240} \mathrm{Pu}$ в поверхностных водах, проводили 
сравнительную характеристику этих показателей для различных морских акваторий, включая Средиземное море.

\section{Материалы и методы}

Для определения альфа-радиоизотопов плутония $\left({ }^{239,240} \mathrm{Pu}\right)$ пробы воды, взвешенного вещества и донных отложений были отобраны в Черном море, преимущественно в западной части в глубоководной и шельфовой зоне, в прибрежных районах, в частности в Севастопольской бухте в постчернобыльский период (Радиоэкологический отклик..., 2008; Терещенко и др., 2012; 2013), а также в Средиземном море и Атлантическом океане у Гибралтарского пролива в 2002 г. (Gulin et al., 2011; Терещенко и др., 2011).

Определения плутония были выполнены согласно современным радиохимическим методикам (Радиоэкологический отклик..., 2008; Терещенко и др., 2011). Процедура основана на термической и химической обработке природных образцов с последующей адсорбцией, очисткой и десорбцией плутония на ионообменных смолах (Dowex 1-X2 или AG 1-Х2 в хлоридной форме с зернами размером 50-100 меш). После очистки и выделения $\mathrm{Pu}$ изготавливали тонкослойные препараты соосаждением плутония с фторидом лантана или проводили его электроосаждение. Полученные тонкослойные образцы измеряли в вакуумных камерах альфа-спектрометрической системы "EG\&G ORTEC OCTETE PC" с помощью низкофоновых кремниевых детекторов. Калибровку энергетических спектров и определение эффективности счета детекторов проводили с использованием стандартов из долгоживущих изотопов плутония ${ }^{242} \mathrm{Pu}$ и америция ${ }^{243} \mathrm{Am}$. Скорость счета фона для каждого из детекторов не превышала 10-5 имп/с. Радиоизотопы ${ }^{239} \mathrm{Pu}$ и ${ }^{240} \mathrm{Pu}$ испускают альфа-частицы, значение энергий которых очень близки $\left({ }^{239} \mathrm{Pu}-5,16\right.$ Мэв (72 \%), 5,14 Мэв $(16,8 \%), 5,11$ Мэв (11,2 \%); ${ }^{240} \mathrm{Pu}-5,17$ Мэв $(75,5$ \%), 5,12 Мэв (24,4%) (Радиоэкологический отклик..., 2008), что приводит к перекрыванию их энергетических альфа-спектров и вследствие этого альфа-спектрометрический метод не позволяет раздельно измерять активность каждого из радитоизотопов ${ }^{239} \mathrm{Pu}$ и ${ }^{240} \mathrm{Pu}$, поэтому в препаратах измеряли суммарную активность этих радионуклидов ${ }^{239+240} \mathrm{Pu}$. Альфа-радиоизотоп плутония ${ }^{242} \mathrm{Pu}$ был добавлен в пробы как радиотрассер для определения химического выхода плутония, который изменялся в диапазоне от 70 до 95 \%. Ошибка определения концентрационной активности ${ }^{239+240} \mathrm{Pu}$ в пробах составляла не более $13 \%$ для образцов донных отложений и 20 \% для образцов воды. Данные по концентрационной активности ${ }^{239+240} \mathrm{Pu}$ в донных отложениях были рассчитаны в Бк/кг сухой массы осадков, в морской воде - в мБк/ $\mathrm{M}^{3}$.

Уровень трофности вод морских акваторий характеризовали по литературным данным, где рассматривались концентрации биогенов в воде, взвешенного вещества, хлорофилла «а», растворенного кислорода и процент насыщения вод кислородом, первичная продукция фитопланктона (Иванов и др., 2006; Chlorophyll-a..., 2010; Финенко и др., 2011; Егоров и др., 2013; http:/www.bruo.ru/ pages/119.html). Использовали также E-TRIX индекс, в котором учтены: суммарное содержание хлорофилла “a” и феофитина “a”, модуль отклонения в относительных значениях растворенного кислорода от 100 \% насыщения; общий фосфор, растворенная форма суммы минерального азота (Vollenveider et al., 1998; Губанов и др., 2012; Лоева и др., 2013).

Для определения потоков плутония в донные отложения (Бк/м².год) и скоростей осадконакопления (мм/год) был применен метод радиоизотопной геохронологической 
реконструкции радиоактивного загрязнения (Радиоэкологический отклик..., 2008; Gulin et al., 2011; Isotopes..., 2013; Егоров и др., 2013), который при наблюдавшихся величинах скорости осадконакопления в Черном море обеспечивал разрешающую способность около 5 лет (Радиоэкологический отклик..., 2008). На основе ретроспективного анализа концентрационной активности ${ }^{239+240} \mathrm{Pu}$ в морской воде был определен период полууменьшения $\left(\mathrm{T}_{1 / 2}\right.$, годы) ${ }^{239+240} \mathrm{Pu}$ в поверхностных черноморских водах традиционным методом (Worldwide..., 2005; Радиоэкологический отклик..., 2008).

\section{Результаты и обсуждение}

Исследование влияния уровня трофности на процессы перераспределения радиоизотопов плутония ${ }^{239+240} \mathrm{Pu}$ было выполнено в постчернобыльский период для черноморских акваторий на разных пространственных масштабах. Рассмотрены процессы седиментационной миграции радиоизотопов плутония в Севастопольской бухте как модельном объекте полузамкнутой акватории. На основе морфометрической модели Севастопольской бухты и с учетом данных по ее загрязнению, скорости седиментации и типам донных отложений было проведено районирование бухты. Она была разделена на 5 частей-зон: I, II, III, IV, V (Стокозов, 2010). В нашей работе дополнительно указана нулевая зона - акватория на внешнем рейде бухты как наиболее чистый район (рис. 1). Для характеристики трофности вод была использована величина первичной продукции в различных частях бухты (Егоров и др., 2013), уровни загрязнения биогенными элементами и концентрация хлорофилла “a”, кислорода и взвешенного вещества (Иванов и др., 2006). По уровню трофности районы бухты расположились по мере возрастания в

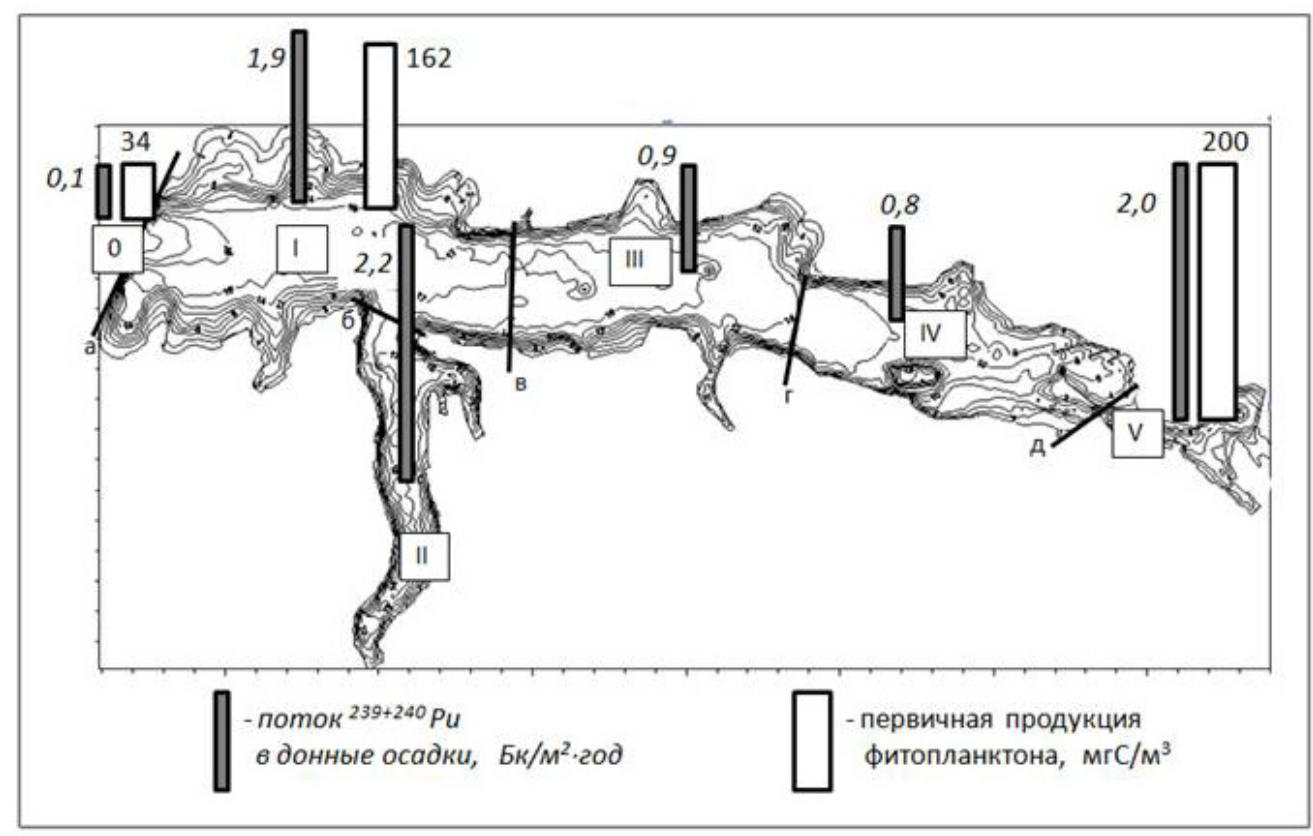

Рис. 1. Потоки седиментационного депонирования ${ }^{239+240} \mathrm{Pu}$ в осадки и первичная продукция фитопланктона в Севастопольской бухте в зонах с разным уровнем трофности, где римскими цифрами указаны номера частей-зон бухты, арабскими цифрами - значения потоков радионуклидов плутония ${ }^{239+240} \mathrm{Pu}$ в донные отложения, первичная продукция фитопланктона, буквами от “а” до “д” - линии, разграничивающие бухту на зоны 
такой последовательности: $0<\mathrm{I}<\mathrm{III}, \mathrm{IV}<\mathrm{V}<$ II. В современный период концентрационная активность ${ }^{239+240} \mathrm{Pu}$ в поверхностных водах в прибрежных акваториях Крыма, включая Севастопольскую морскую акваторию, была достаточно однородна, в период 2010-2014 гг. не превышала 0,1 мБк/ $\mathrm{M}^{3}$ (Tereshchenko et al., 2014) и тем самым не влияла на изменение величины потока ${ }^{239+240} \mathrm{Pu}$ в донные отложения. Поэтому в качестве характеристического параметра в Севастопольской бухте был выбран среднегодовой седиментационный поток радиоизотопов плутония ${ }^{239+240} \mathrm{Pu}$ в донные осадки.

Результаты анализа интенсивности седиментационной миграции плутония в донные осадки в Севастопольской бухте в акваториях с разным уровнем трофности представлены на рис. 1. Согласно биогеохимическому районированию (Иванов и др., 2006) по загрязнению, прежде всего биогенными элементами, части III и IV были отнесены к одному уровню трофности и, как видно на рис. 1, потоки плутония в донные отложения в этих зонах составили близкие величины, равнялись соответственно 0,9 и 0,8 Бк ${ }^{239+240} \mathrm{Pu} / \mathrm{M}^{2} \cdot$ год.

Сравнение загрязненности биогенными элементами зоны II, которую называют Южной бухтой, с концентрациями неорганического фосфора, азота и кремния в Севастопольской бухте выявило, что в зоне II они были в несколько раз выше (Иванов и др., 2006). Это указывало на то, что уровень трофности вод в акватории зоны II был самый высокий в период исследований, интенсивность седиментации альфа-радиоизотопов плутония была также самой высокой в бухте и достигала 2,2 Бк ${ }^{239+240} \mathrm{Pu} / \mathrm{M}^{2} \cdot$ год. Самые низкие значения среднегодового потока седиментационного депонирования ${ }^{239+240} \mathrm{Pu}$ в осадки и первичной продукции фитопланктона наблюдали в боксе 0 - на внешнем рейде Севастопольской бухты (рис. 1).

Анализ данных показал, что в разных районах Севастопольской бухты с повышением уровня трофности седиментационный поток плутония в донные отложения возрастает (рис. 1). Исключение составила только зона I, где значения потока плутония более высокие, а уровень трофности несколько ниже, чем в зонах III и IV. Это можно объяснить тем, что заградительные молы, построенные на выходе из бухты (вдоль линии “a” на рис. 1), привели к изменению гидродинамического режима в этой акватории и, исполняя роль искусственного гидрологического барьера, способствовали усиленному осадконакоплению не только за счет увеличения количества взвеси, но и под влиянием гидродинамических факторов. При этом доля биогенной взвеси в зонах I и $\mathrm{V}$, для которых характерны более высокие потоки плутония, составляла 33-47 \% от общей взвеси, а в зонах III и IV она не превышала $12 \%$ (Гулин и др., 2013). Полученные данные свидетельствуют о том, что в масштабе одной бухты увеличение трофности вод в ее отдельных акваториях способствует усилению седиментационного потока радионуклидов плутония в донные осадки и увеличению самоочистительной способности толщи вод от ${ }^{239+240} \mathrm{Pu}$.

При рассмотрении седиментационного депонирования ${ }^{239+240} \mathrm{Pu}$ в масштабе моря была исследована западная часть водоема. В западной части Черного моря в постчернобыльский период на ранних стадиях после аварии на Чернобыльской АЭС (ЧАЭС) общим источником радиоактивного загрязнения служили атмосферные выпадения. В более поздние сроки в этом районе присутствовали два других больших локальных источника поступления ${ }^{239+240} \mathrm{Pu}$ водным путем от радиоактивного загрязнения после аварии на ЧАЭС - сток 
вод Днепра и Дуная. Они вносили локальные изменения в поле распределения концентрационной активности ${ }^{239+240} \mathrm{Pu}$ в воде (Радиоэкологический отклик..., 2008; Tereshchenko et al., 2014), что формировало локальные повышения концентрационных активностей плутония в близлежащих акваториях и сказывалось на величине седиментационного потока ${ }^{239+240} \mathrm{Pu}$ в осадки. Поэтому в качестве сравнительного характеристического параметра миграции плутония как элемента, которому свойствен педотропный тип биогеохимического поведения в водных экосистемах и имеющего высокое сродство к частицам, для западной части Черного моря была выбрана скорость осадконакопления, определяющая седиментационный поток плутония в донные отложения. Трофность акваторий характеризовали по E-TRIX индексу (Vollenveider et al., 1998; Губанов и др., 2012). В соответствии с этим индексом Дунайское взморье было отнесено к акватории с очень высоким уровнем трофности (E-TRIX индекс $>6$ ). Устье Днепра - акватория с высоким уровнем (E-TRIX индекс $>5$ ). Отдельные мелководные прибрежные полузакрытые акватории у западного побережья Крымского полуострова - районы со средним уровнем $(4<$ E-TRIX индекс $>5$ ), а акватории над материковым склоном и в абиссали моря - зоны с низким уровнем трофности (E-TRIX индекс < 4) (Губанов и др., 2012; Лоева и др., 2013). Такой же характер распределения трофности вод в море подтверждают и данные по биомассе фитопланктона и его первичной продукции (Финенко и др., 2011). Результаты рассмотрения влияния разного уровня трофности вод на скорость осадконакопления в масштабе водоема на примере западной части Черного моря представлены на рис. 2 .

Несмотря на различную долю биогенной взвеси в осадконакоплении в открытых и при- брежных районах Черного моря и ее преобладание в открытых районах моря (Митропольский и др., 1982), с увеличением трофности вод скорость осадконакопления возрастала. На взморье Дуная и Днепра, где наблюдали высокие уровни трофности вод, определены максимальные скорости осадконакопления, 11,5 и 9,2 мм/год, а минимальные - в глубоководной котловине моря - 0,4 мм/год (рис. 2). Соответственно возрастала и интенсивность депонирования плутония в осадки.

Черное море наряду с Мраморным и Азовским морями относится к бассейну Средиземного моря. В самом Средиземном море выделяют ряд морей: Альборан, Балеарское, Лигурийское, Тирренское, Адриатическое, Ионическое и Эгейское, Ливийское, Кипрское и Левантийское. Черное море связано водообменном со Средиземным морем через проливы Дарданеллы и Босфор, Мраморное море. Благодаря более высокому уровню вод в Черном море по сравнению с Мраморным и разности солености вод Черного и Средиземного морей, водообмен происходит по постоянным противоположно направленным течениям: верхнему - распресненному и нижнему - с более солеными водами (Иванов, Белокопытов, 2011). Черное море по трофическому статусу относится к мезотрофным морским водоемам, и только отдельные прибрежные районы, преимущественно вблизи рек, имеют эвтрофный статус (Финенко и др., 2011; Лоева и др., 2013). Средиземное море - олиготрофный водоем, за исключением отдельных в основном прибрежных акваторий с более высоким трофным статусом (http://www.bruo.ru/pages/119. html; Chlorophyll-a..., 2010). Поэтому представляют несомненный интерес определение и сравнительный анализ радиоэкологических параметров миграции и перераспределения радиоизотопов плутония ${ }^{239+240} \mathrm{Pu}$ на масштабе большого средиземноморского бассейна на 


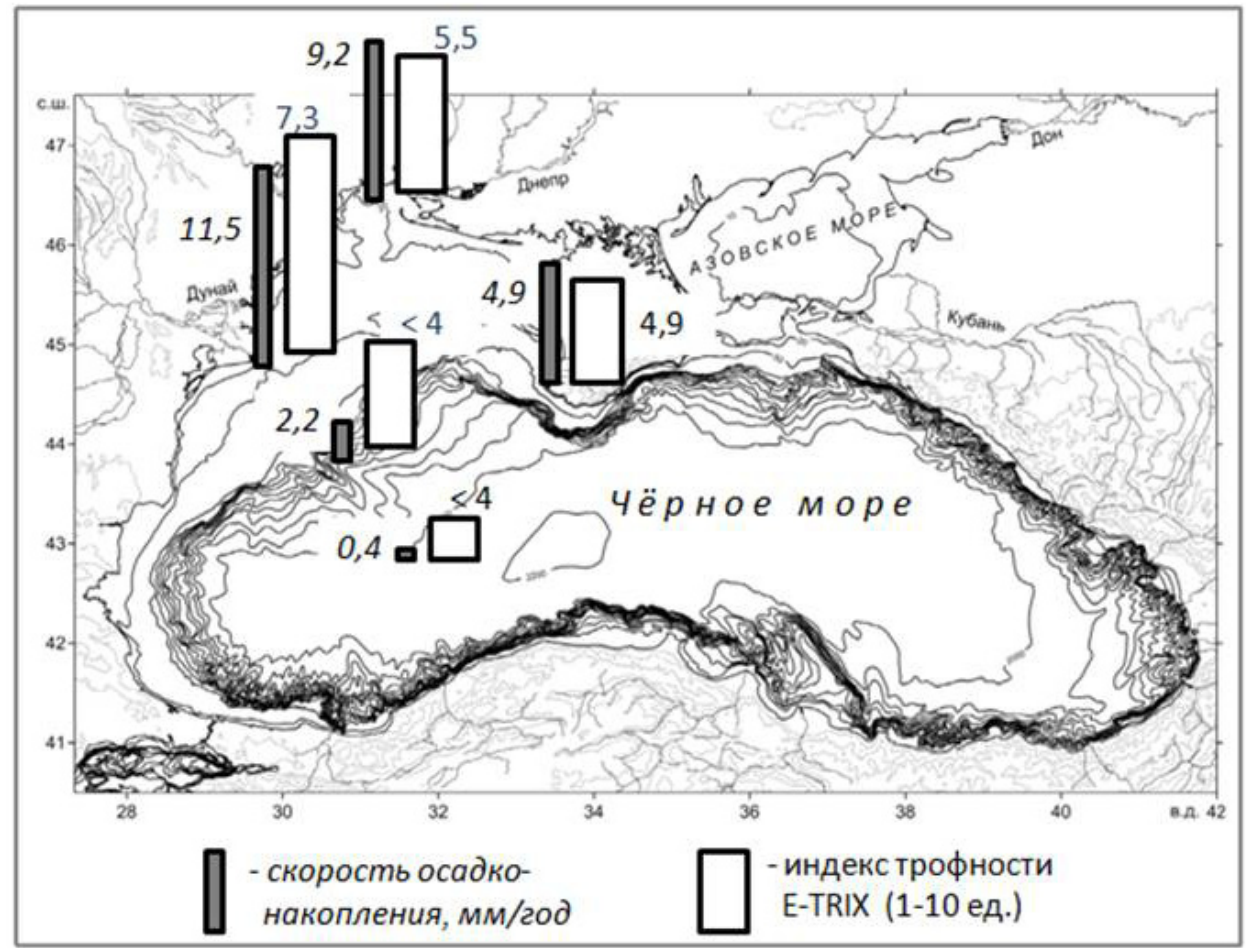

Рис. 2. Скорость осадконакопления (Гулин и др., 2000; Мирзоева, 2009; Терещенко и др., 2012, 2013; Егоров и др., 2013) в акваториях Черного моря с разным уровнем трофности по индексу E-TRIX (Губанов и др., 2012; Лоева и др., 2013)

примере двух морей с разным трофическим статусом: Черного и Средиземного.

Результаты сравнения радиоэкологических характеристик миграции радиоизотопов плутония ${ }^{239+240} \mathrm{Pu}$ (Gulin et al., 2011; Терещенко и др., 2011; Tereshchenko et al., 2014) в Черном и Средиземном (Ионическом) морях приведены на рис. 3. Удельная активность поверхностной воды в отношении ${ }^{239+240} \mathrm{Pu}$ в 1986 г. после аварии на ЧАЭС в Средиземном море составляла (20 \pm 5$)$ мБК/ м $^{3}$ (Worldwide..., 2005), в Черном море - $(12 \pm 5)$ мБк/м ${ }^{3}$ (Buesseler, Livingston, 1996). К 2002 г. она уменьшилась в Черном море в 7, а в Средиземном в 2,2 раза (рис. 3) (Терещенко и др., 2011). Период полууменьшения $\left(\mathrm{T}_{1 / 2}\right){ }^{239,240} \mathrm{Pu}$ в черноморских поверхностных водах был оценен в $4 \pm 3$ года (Терещенко и др., 2015), что более чем в три раза меньше, нежели таковой для Средизем- ного моря (13 \pm 2 года) (Worldwide..., 2005). В Атлантическом океане в Пригибралтарском районе $\mathrm{T}_{1 / 2}{ }^{239+240} \mathrm{Pu}$ был меньше, чем в Средиземном море (рис. 3), что, вероятно, связано с большим количеством взвеси и, в частности, планктона в этих водах (http://www.bruo. ru/pages/119.html). Более высокое значение $\mathrm{T}_{1 / 2}{ }^{239+240} \mathrm{Pu}$ по сравнению с Черным морем, очевидно, связано с отсутствием восстановительных свойств в атлантических водах в отличие от черноморских вод, которые глубже 100-150 м содержат сероводород (Молисмология..., 1992). В сероводородной восстановительной зоне прочность связывания плутония с частицами взвеси увеличивается (Sanchez et al., 1991), что препятствует его ремобилизации в водную среду и уменьшает время пребывания плутония в воде. Следовательно, повышенный уровень трофности черноморских 


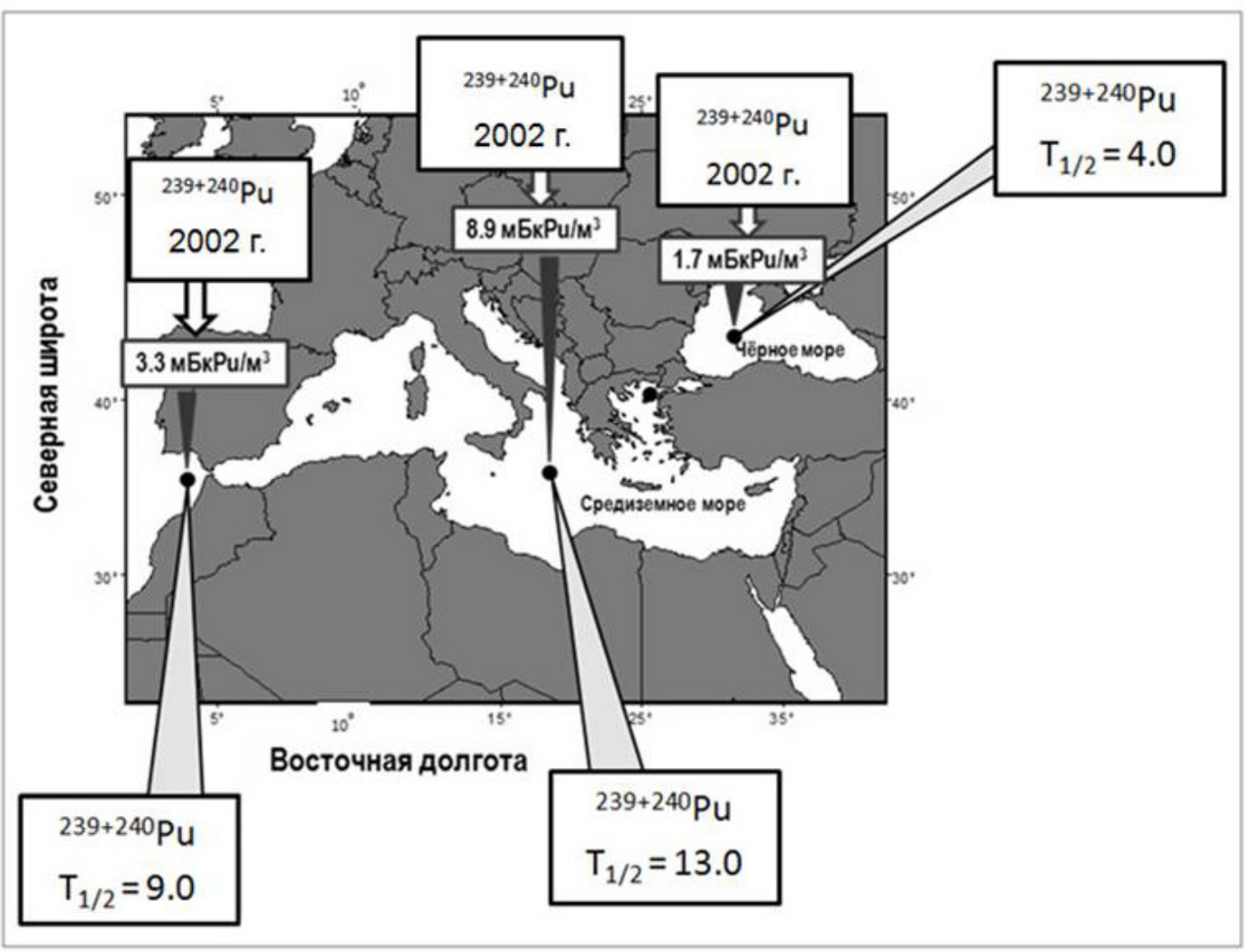

Рис. 3. Удельная активность воды в отношении ${ }^{239+240} \mathrm{Pu}$, мБк/м ${ }^{3}$ (черные диаграммы) и периоды полууменьшения ${ }^{239+240} \mathrm{Pu}\left(\mathrm{T}_{1 / 2}\right.$, годы) в поверхностных водах Черного, Средиземного морей и Атлантического океана у Гибралтарского пролива (Worldwide..., 2005; Gulin et al., 2011; Терещенко и др., 2011)

вод, наличие восстановительных условий в их толще и поливалентные свойства плутония ускоряют процесс перераспределения радиоизотопов плутония в экосистеме Черного моря в пользу донных осадков, усиливая тем самым выраженность педотропного типа биогеохимического поведения плутония (Терещенко и др., 2012).

Это подтверждается высокими коэффициентами накопления ${ }^{239+240} \mathrm{Pu}$ черноморскими донными отложениями, которые составляют величины $\mathrm{n} \times 10^{4-} \mathrm{n} \times 10^{5}$ (Терещенко и др., 2011; 2012), что приводит к тому, что в черноморских мезотрофных водах скорость ухода из водного столба радионуклидов плутония выше, чем в средиземноморских олиготрофных во- дах. Это оказывает влияние на формирование радиоэкологической ситуации в морях и ее изменение вследствие разной скорости миграции и типа биогеохимического поведения плутония в этих морских водоемах.

Движение вод через пролив Босфор происходит из Черного моря по верхнебосфорскому, а в Черное море - по нижнебосфорскому течению. По данным разных авторов о водообмене через пролив, среднегодовые объемы вод различаются в несколько раз (Иванов, Белокопытов, 2011). Поэтому в расчетах нами были использованы средние значения годового объема стока вод из Черного моря с верхнебосфорским течением - 362 км $3 /$ год и приток в Черное море с нижнебосфорским течением - 
Таблица. Удельная активность воды в отношении ${ }^{239+240} \mathrm{Pu}$ в Черном и Средиземном морях и движение с водными массами радионуклидов плутония через пролив Босфор в постчернобыльский период

\begin{tabular}{|c|c|c|c|c|}
\hline \multirow{2}{*}{$\begin{array}{c}\text { Период } \\
\text { исследования, } \\
\text { год }\end{array}$} & \multicolumn{2}{|c|}{$\begin{array}{c}\text { Удельная активность воды } \\
\text { в отношении }\end{array}$} & \multicolumn{2}{|c|}{$\begin{array}{c}\text { Поступление }{ }^{239+240} \mathrm{Pu} \\
\text { через пролив Босфор, ГБк/год }\end{array}$} \\
\cline { 2 - 5 } & в Черном море & $\begin{array}{c}\text { в Средиземном } \\
\text { море }\end{array}$ & из Черного моря & в Черное море \\
\hline 1986 & 12 & 20 & 4,34 & 2,90 \\
1990 & 7,7 & 15,9 & 2,79 & 2,31 \\
1992 & 5,2 & 14,2 & 1,88 & 2,06 \\
1994 & 3,5 & 12,5 & 1,27 & 1,81 \\
$2002-2003$ & 1,7 & 8,9 & 0,62 & 0,58 \\
$2012-2014$ & 0,5 & 4,0 & 0,18 & \\
\hline
\end{tabular}

145 км³/год. Оценки потоков ${ }^{239+240} \mathrm{Pu}$ в разные периоды после аварии на ЧАЭС через пролив Босфор, выполненные на основе измеренных концентрационных активностей плутония в морских поверхностных водах и рассчитанные по аппроксимационным уравнениям, описывающим экспоненциальное снижение ${ }^{239+240} \mathrm{Pu}$ в черноморских (Терещенко и др., 2015) и средиземноморских (Worldwide..., 2005) водах, представлены в табл.

Как видно из приведенных в табл. данных, сразу после чернобыльских радиоактивных выпадений в 1986 г. результирующий среднегодовой поток ${ }^{239+240} \mathrm{Pu}$ с босфорскими водами был направлен в сторону Средиземного моря. Вынос плутония через Босфор превышал его поступление в Черное море. По прошествии примерно 6 лет после аварии на ЧАЭС в результате биогеохимических процессов произошло перераспределение ${ }^{239+240} \mathrm{Pu}$ в экосистемах этих морей. Поступление ${ }^{239+240} \mathrm{Pu}$ в Черное море через Босфор стало превышать его вынос. Это было обусловлено тем, что вследствие мезотрофного статуса черноморских вод их самоочищение от плутония происходило более интенсивно и концентрационная активность ${ }^{239+240} \mathrm{Pu}$ в черноморских водах снижалась быстрее, чем таковая в средиземноморских водах (рис. 3). К 2002 г. количество выносимого ${ }^{239+240} \mathrm{Pu}$ из
Черного моря уменьшилось более чем в 7 раз, а поступление ${ }^{239+240} \mathrm{Pu}$ в Черное море со средиземноморскими водами снизилось менее чем в 2 раза. В результате таких изменений средиземноморские воды и в 2012-2014 гг. продолжали быть источником загрязнения черноморских водных масс ${ }^{239+240} \mathrm{Pu}$ (рис. 4).

Поток поступления плутония со средиземноморскими водами, пройдя свой максимум, снизился и определялся соотношением концентрационных активностей ${ }^{239+240} \mathrm{Pu}$ в черноморских и средиземноморских водах. Не привязываясь к абсолютным значениям поступления радиоизотопов плутония в Черное море со средиземноморскими водами, учитывая неточность количественных оценок водообмена через Босфор (Иванов и др., 2006), а также возможное влияние синоптических, сезонных и других факторов на эти процессы, можно заключить, что полученные данные указывают на тенденцию изменения радиоэкологического статуса Черного и Средиземного морей в отношении перераспределения плутония в средиземноморском бассейне в постчернобыльский период. Это связано с более высокой скоростью самоочищения поверхностных черноморских вод от радионуклидов плутония ${ }^{239+240} \mathrm{Pu}\left(\mathrm{T}_{1 / 2}=4\right.$ года) по сравнению со средиземноморскими водами $\left(\mathrm{T}_{1 / 2}=13\right.$ лет), которые связаны со ско- 


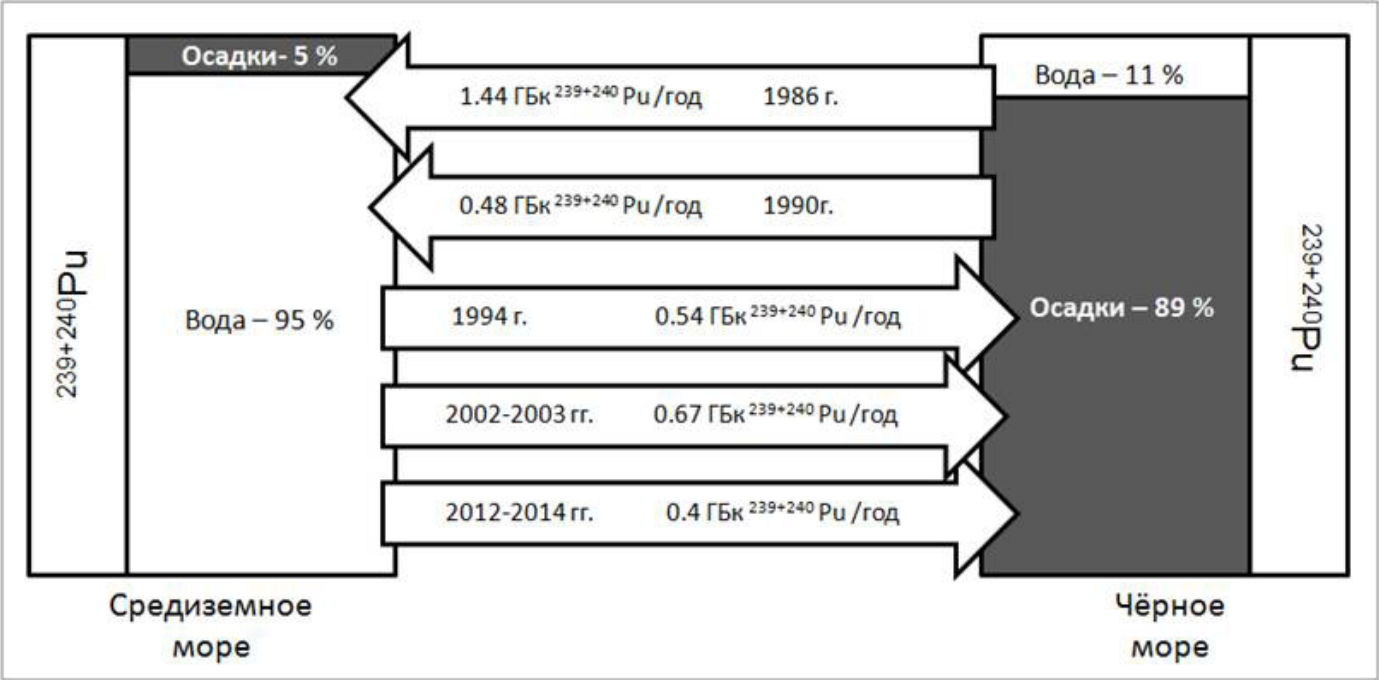

Рис. 4. Перераспределение и миграция ${ }^{239+240} \mathrm{Pu}$ внутри и между Черным и Средиземным морями как водоемами с различным уровнем трофности: белый прямоугольник-доля $(\%){ }^{239+240} \mathrm{Pu} \mathrm{в} \mathrm{воде} \mathrm{моря;} \mathrm{темный}$ прямоугольник - доля (\%) ${ }^{239+240} \mathrm{Pu}$ в донных осадках моря; стрелками обозначены результирующие годовые потоки ${ }^{239+240} \mathrm{Pu}$, поступающие через пролив Босфор, и их направленность в разные периоды после аварии на ЧАЭС

ростью осадконакопления, с разным уровнем трофности вод морей и, как следствие, с различным перераспределением радионуклидов плутония между водной средой и донными отложениями (рис. 4). В зависимости от разности концентраций плутония в средиземноморских и черноморских водах Средиземное море на определенном этапе в период после аварии на ЧАЭС может выступать источником поступления плутония в Черное море, хотя более удалено от источника загрязнения. Черное море, наоборот, служит биогеохимическим барьером на пути миграции плутония из его водосборного бассейна в Средиземное море и стало приемником плутония, поступающего со средиземноморскими водами на определенном этапе в постчернобыльский период.

\section{Заключение}

В результате проведенных исследований установлено, что седиментационное посту- пление радионуклидов плутония ${ }^{239+240} \mathrm{Pu}$ из водных масс в донные отложения в Черном море в различных его акваториях усиливается в районах с повышенным уровнем трофности вод. Более высокий уровень трофности вод наряду с другими факторами приводит к более выраженному проявлению педотропных свойств биогеохимического поведения плутония в экосистеме, т.е. способствует его более быстрому перераспределению из водных масс и депонированию в донные осадки. Такое влияние уровня трофности вод на седиментационный поток поступления плутония в осадки характерно как для прибрежных морских районов (на примере Севастопольской бухты), так и для всего Черного моря в целом (на примере западной части моря). Самые высокие скорости осадконакопления в исследуемых акваториях наблюдали в районах с самым высоким уровнем трофности - взморье Дуная и Днепра, относящиеся к водам с очень 
высоким $(\mathrm{E}-\mathrm{TRIX}=7,3)$ и высоким уровнем трофности (E-TRIX $=5,5)$ соответственно.

Различные уровни трофности в близлежащих морях средиземноморского бассейна, связанных между собой водообменом, определяют различный радиоэкологический статус водоемов в бассейне в отношении миграции радионуклидов плутония. Черное море как водоем с мезотрофным статусом основную массу поступивших радионуклидов плутония ${ }^{239+240} \mathrm{Pu}$ аккумулирует в донных осадках $(89,3$ \%) и в постчернобыльский период служит биогеохимическим барьером на пути миграции плутония чернобыльского происхождения в Средиземное море. Период полууменьшения содержания ${ }^{239,240} \mathrm{Pu}$ в черноморских поверхностных водах составил (4+3) года, что в три раза меньше, чем таковой для вод олиготрофного Средиземного моря (13+2 года). Это характеризует высокую способность поверхностных вод Черного моря к самоочищению от плутония путем его депонирования в донных отложениях, отражая проявление педотропного типа биогеохимического поведения этого элемента в Черном море. Средиземное море как водоем с олиготрофными водами характеризуется длительным пребыванием радионуклидов плутония в толще вод и сохранением в течение продолжительного периода повышенных концентраций ${ }^{239+240} \mathrm{Pu}$ в воде. Нахождение около 95 \% плутония в средиземноморских водных массах может приводить к поступлению дополнительного количества радионуклидов плутония ${ }^{239+240} \mathrm{Pu}$ в Черное море со средиземноморскими водами в определенные периоды после ядерных инцидентов в результате водообмена через Босфор. Так, в случае аварии на ЧАЭС с начала 90-х гг. ХХ в. по настоящее время поступление плутония со средиземноморскими водами превышает его вынос из Черного моря через пролив Босфор. Наблюдавшееся распределение плутония между водными массами и донными осадками в Средиземном море (соответственно 95 и 5 \%) свидетельствует о том, что в условиях олиготрофных морских экосистем биогеохимическое поведение плутония соответствует гидротропному типу. Увеличение трофности вод ведет к увеличению концентрации взвеси и скорости осадконакопления, что наряду с другими факторами играет существенную роль в процессах перераспределения ${ }^{239+240} \mathrm{Pu}$ на различных пространственных масштабах. Уровень трофности вод оказывает влияние на радиоэкологический статус водоема в бассейне в отношении миграции радионуклидов плутония и на биогеохимический тип поведения радиоизотопов плутония в морской экосистеме.

\section{Список литературы}

Губанов В.И., Ковригина Н.П., Родионова Н.Ю., Царина Т.В. (2012) Оценка уровня трофности морских вод в районе Карадагского природного заповедника (Черное море). Современные рыбохозяйственные и экологические проблемы Азово-Черноморского региона. Материаль Международной конференции. Керчь, 2012. T. 1. Керчь, ЮгНИРО, с. 192 - 195 [Gubanov V.I., Kovrigina N.P., Rodionova N.Y., Tsarina T.V. (2012) Evaluation of the trophic levels of marine waters near Karadag (the Black Sea). Modern fisheries management and ecological problems of the AzovBlack Sea Region. Procceedings of the international conference. Kerch, 2012. Vol. 1. Kerch, South Research Institute of Fisheries and Oceanography (YugNIRO), p. 192 - 195 (in Russian)]

Гулин С.Б., Сидоров И.Г., Гулина Л.В. (2013) Биогенная седиментация в Черном море: радиотрассерное исследование. Морской экологический журнал, 12 (2): 19-25 [Gulin S.B., Sidorov 
I.G., Gulina L.V. (2013) Biogenic sedimentation in the Black Sea: radiotracer study. Marine Ecological Journal [Morskoi Ecologichesky Zhurnal], 12 (2): 19-25 (in Russian)]

Егоров В.Н., Гулин С.Б., Поповичев В.Н., Мирзоева Н.Ю., Терещенко Н.Н., Лазоренко Г.Е., Малахова Л.В., Плотицына О.В., Малахова Т.В., Проскурнин В.Ю., Сидоров И.Г., Гулина Л.В., Стецюк А.П., Марченко Ю.Г. (2013) Биогеохимические механизмы формирования критических зон в Черном море в отношении загрязняющих веществ. Морской экологический журнал, 12 (4): 5-26 [Egorov V.N., Gulin S.B., Popovichev V.N., Mirzoeva N.Yu., Tereshchenko N.N., Lazorenko G.E., Malakhova L.V., Plotitsyna O.V., Malakhova T.V., Proskurnin V.Yur., Sidorov I.G., Gulina L.V., Stetsyuk A.P., Marchenko Yu.G. (2013) The biogeochemical mechanisms of the critical areas formation in the Black Sea against pollution. Marine Ecological Journal [Morskoi Ecologicheskiy Zhurnal], 12 (4): 5-26 (in Russian)]

Иванов В.А., Овсяный Е.И., Репетин Л.Н., Игнатьева О.Г. (2006)Гидролого-гидрохимический режим Севастопольской бухты и его изменения под воздействием климатических и антропогенных факторов. Севастополь, МГИ НАН Украины, 90 с. [Ivanov V.A., Ovsyaniy E.I., Repetin L.N., Ignatieva O.G. (2006) Hydrological and hydrochemical regime of Sevastopol Bay and its changes under the influence of climatic and anthropogenic factors. Sevastopol, Marine Hydrophisical Institute NAS of Ukraine, 90 p. (in Russian)]

Иванов В.А., Белокопытов В.Н. (2011) Океанография Черного моря. Севастополь, НАН Украины, Морской гидрофизический институт, 212 с. [Ivanov V.A., Belokopytov V.N. (2011) Oceanography of the Black Sea. Sevastopol, NAS of Ukraine, Marine Hydrophysical Institute, 212 p. (in Russian)]

Лоева И.Д., Украинский В.В., Орлова И.Г., Ковалишина С.П. (2013) Современное экологическое состояние северо-западной части Черного моря. Экологическая безопасность прибрежной и шельфовой зон и комплексное использование ресурсов шельфа, 27: 237-242 [Loyeva I.D., Ukrainskiy V.V., Orlova I.G., Kovalishina S.P. (2013) The current ecological state of the Northwestern Black Sea. Ecological safety of coastal and shelf zones and complex use of shelf resources [Ecologicheskaya bezopasnost pribrezhnoy i shelfovoi zon i kompleksnoye ispolzovanie resursov shelfa], 27: 237-242 (in Russian)]

Митропольский А.Ю., Безбородов А.А., Овсяный Е.И. (1982) Геохимия Черного моря. Киев, Наукова думка, 144 c. [Mitropolskiy A.Yur., Bezborodov A.A., Ovsyaniy E.I. (1982) Geochemistry of the Black Sea. Kiev, Naukova dumka, 144 p. (in Russian)]

Молисмология Черного моря (1992) Г.Г. Поликарпов (ред.). Киев, Наукова думка, 304 с. [Molismology of the Black Sea (1992) G.G. Polikarpov (ed.) Kiev, Naukova dumka, 304 p. (in Russian)]

Морская радиохемоэкология и проблема загрязнений (1984) Г.Г. Поликарпов (ред.) Киев, Наук. думка, 184 с. [Marine radiochemoecology and pollution problems (1984) G.G. Polikarpov (ed.) Kiev, Naukova Dumka, 184 p. (in Russian)]

Плутоний. Фундаментальные проблемы (2003) Пер. с англ. под ред. Б.А. Надытко, А.Ф. Тимофеевой. Саров, РФЯЦ, 495 с. [Plutonium. Fundamental problems (2003) Translated from English. B.A. Nadytko, L.F. Timofeeva (eds.) Sarov, Russian Federation Nuclear Center, 498 p. (in Russian)]

Поликарпов Г.Г., Егоров В.Н. (1986) Морская динамическая радиохемоэкология. М., Энергоатомиздат, 176 с. [Polikarpov G.G., Egorov V.N. (1986) Marine dynamic radiochemoecology. Moscow, Energoatomizdat, 176 p. (in Russian)] 
Радиоэкологический отклик Черного моря на чернобыльскую аварию (2008) Г.Г. Поликарпов, В.Н. Егоров (ред.) Севастополь, ЭКОСИ-Гидрофизика, 667 с. [Radioecological response of the Black Sea to the Chernobyl accident (2008) G.G. Polikarpov, V.N. Egorov (eds.) Sevastopol, ECOSI-Gydrophysica, 667 p. (in Russian)]

Стокозов Н.А. (2010) Морфометрические характеристики Севастопольской и Балаклавской бухт. Экологическая безопасность прибрежной и шельфовой зон и комплексное использование ресурсов шельфа, 23: 198-208 [Stokozov N.A. (2010) Morphometric characteristics of Sevastopol and Balaklava Bays. Ecological safety of coastal and shelf zones and complex use of shelf resources [Ecologicheskaya bezopasnost pribrezhnoy i shelfovoi zon i kompleksnoye ispolzovanie resursov shelfa], 23: 198-208 (In Russian)]

Терещенко Н.Н. (1986) Экспериментальное изучение деевтрофирующей функиии черноморской водоросли Ulva rigida Ag. в отношении фосфат-ионов. Дис. ... канд. биол. наук. Севастополь, Ин-т биологии южных морей им. А.О. Ковалевского, [б. и.], 137 с. [Tereshchenko N.N. (1986) Experimental study of the deeutrophying function of the Black Sea algae Ulva rigida Ag. with regard to phosphate-ions. Dis. ... Cand. of Biol. Science. Sevastopol, The A.O. Kovalevsky Institute of Biology of the Southern Seas, [b. i.], 137 p. (in Russian)]

Терещенко Н.Н. (2011) Ведущая роль донных отложений в перераспределении плутония в черноморских экосистемах. Наукові праиі: науково-методичний журнал. Техногенна безпека, 169 (157): 63-70 [Tereshchenko N.N. (2011) Leading role of bottom sediment in the redistribution of plutonium in the Black Sea ecosystems. Scientific Papers: Scientific-methodical journal. Technogenic safety [Naukovi praci: Naukovo-metodichny Jurnal. Technogenna bezpeka], 169 (157): 63-70 (in Russian)]

Терещенко Н.Н., Гулин С.Б., Проскурнин В.Ю. (2011) Модифицированная методика определения плутония в морской воде. Экологическая безопасность прибрежной и шельфовой зон и комплексное использование ресурсов шельфа, 25 (1): 241-251 [Tereshchenko N.N., Gulin S.B., Proskurnin V.Yur. (2011) Modified method of determination of plutonium in the sea water. Ecological safety of coastal and shelf zones and complex use of shelf resources [Ecologicheskaya bezopasnost pribrezhnoy i shelfovoi zon i kompleksnoye ispolzovanie resursov shelfa], 25 (1): 241-251 (in Russian)]

Терещенко Н.Н., Гулин С.Б., Проскурнин В.Ю., Дука М.С. (2015) Радиоэкологические параметры миграции ${ }^{239+240} \mathrm{Pu}$ в морской среде и их связь с биогеохимическими особенностями экосистемы Черного моря. Современные проблемы эволюции и экологии. Сб. материалов международной конферениии. Ульяновск, 2015. Ульяновск, УлГПУ, с. 118 - 124 [Tereshchenko N.N., Gulin S.B., Proskurnin V.Y., Duka M.S. Radiological parameters of the ${ }^{239+240} \mathrm{Pu}$ migration in the marine environment and their relationship to the biogeochemical characteristics of the of the Black Sea ecosystem. Modern problems of evolution and ecology. Proceedings of the international conference. Ulyanovsk, 2015. Ulyanovsk, Ulyanovsk State Pedagogical University, p. 118 - 124 (in Russian)]

Терещенко Н.Н., Поликарпов Г.Г., Крылова Т.А. (2012) Барьерная роль Черного моря в отношении ${ }^{239,240} \mathrm{Pu},{ }^{137} \mathrm{Cs},{ }^{90} \mathrm{Sr}$ - основных техногенных дозообразующих радионуклидов в постчернобыльский период. Экосистемы, их оптимизация и охрана, 7: 243-250 [Tereshchenko N.N., Polikarpov G.G., Krylova T.A. (2012) Barrier role of the Black sea against ${ }^{239,240} \mathrm{Pu},{ }^{137} \mathrm{Cs},{ }^{90} \mathrm{Sr}-$ main technogenic dose-forming radionuclides in the post-Chernobyl period. Ecosystems, their optimization and protection [Ecosystemi, ikh optimizaciya i okhrana], 7: 243-250 (in Russian)] 
Терещенко Н.Н., Проскурнин В.Ю., Гулин С.Б., Крылова Т.А. (2013) Радиоэкологический мониторинг плутония в донных отложениях севастопольских бухт. Экологическая безопасность прибрежной и шельфовой зон и комплексное использование ресурсов шельфа, 27: 289-293 [Tereshchenko N.N., Proskurnin V.Yur., Gulin S.B., Krylova T.A. (2013) Radioecological monitoring of plutonium in the bottom sediments of Sevastopol bays. Ecological safety of coastal and shelf zones and complex use of shelf resources [Ecologicheskaya bezopasnost pribrezhnoy i shefovoi zon i kompleksnoye ispolzovanie ikh resursov], 27: 289-293 (in Russian)]

Трапезников А.В., Трапезникова В.Н. (2006) Радиоэкология пресноводных экосистем. Екатеринбург, Изд-во УрГСХА, 390 с. [Trapeznikov A.V., Trapeznikova V.N. (2006) Radioecology of freshwater ecosystems. Yekaterinburg, Ural State Academy of Agriculture, 390 p. (in Russian)]

Финенко 3.3., Чурилова Т.Я., Суслин В.В. (2011) Оценка биомассы фитопланктона и первичной продукции в Черном море по спутниковым данным Промысловые биоресурсы Черного и Азовского морей. Севастополь, ЭКОСИ-Гидрофизика, с. 220-236 [Finenko Z.Z., Churilova T.Yu., Suslin V.V. (2011) Assessment of phytoplankton biomass and primary production in the Black Sea based on satellite data. Commercial Bioresources of the Black and Azov Seas. Sevastopol, ECOSIGydrophysica, p. 220-236 (in Russian)]

Buesseler K.O., Livingston H.D. (1996) Natural and man-made radionuclides in the Black Sea. Radionuclides in the Oceans. Input and Inventories. France, IPSN, Editions de Physique, p. 201-217

Chlorophyll-a concentrations in European seas, 2008. (Published 06 Dec 2010) http://www.eea. europa.eu/data-and-maps/figures/map-of-summer-chlorophyll-a-concentrations-observed-in

Gulin S.B., Egorov V.N., Polikarpov G.G., Osvath I.B., Stokozov N.A., Mirzoeva N.Yu., Tereshchenko N.N., Gulina L.V., Proskurnin V.Yu. (2011) Radiotracers in the Black Sea: a tool for marine environmental assessments. Isotopes in Hydrology, Marine Ecosystems and Climate Change Studies: Intern. Symp. Abstr. 27 March - 1 April 2011, Monaco. Viena, IAEA, p. 217

Isotopes in Hydrology, Marine Ecosystems and Climate Change Studies (2013) Proceedings of the International Symposium, Monaco, 2011. Vol. 2. Vienna, IAEA, 636 p.

Sanchez A.L., Gastaud J., Noshkin V., Buesseler K.O. (1991) Plutonium oxidation states in the southwestern Black Sea: evidence regarding the origin of the cold intermediate layer. Deep Sea Research, 38 (2): 845-853

Santschi P.H., Honeyman B.D. (1989) Radionuclides in aquatic environments. Radiation Physic and Chemistry Journal, 34 (2): 213-240

Tereshchenko N.N., Mirzoyeva N.Yu., Gulin S.B., Milchakova N.A. (2014) Contemporary radioecological state of the North-western Black Sea and the problems of environment conservation. Marine Pollution Bulletin, 81 (1): 7-23

Vollenveider R.A., Giovanardi F., Montanari G., Rinaldi A. (1998) Characterization of the trophic conditions of marine coastal waters, with special reference to the NW Adriatic Sea. Proposal for a trophic scale, turbidity and generalized water quality index. Environmetrics, 9 (3): 329-357

Worldwide Marine Radioactivity Studies (WOMARS). Radionuclide Levels in Oceans and Seas (2005) Vienna, IAEA, 187 p. 